\title{
The Antagonism of Potassium and Catecholamines on the Vascular Tone of Isolated Arterial Segments
}

Potassium ions are released by exercising muscle fibres and their concentration in the venous outflow is measurably increased within a few seconds ${ }^{1,2}$. Furthermore it is known that a small increase in the potassium concentration dilates arteries - proved on limb preparations and by our own investigations on isolated arterial segments ${ }^{3-5}$. Therefore one can assume that potassium might be one of the agents decreasing arterial tone during muscular activity.

Noradrenaline (NA) or sympathetic stimulation are known to increase arterial tone in vivo as well as in vitro. But muscle blood flow increases during exercise in spite of the overall increased sympathetic activity ${ }^{6,7}$. In functional hyperemia, local vasodilatators suppress the vasoconstriction induced by adrenergic compounds as well as by sympathetic stimulation ${ }^{8-10}$. The mechanism of this inhibition is not yet clarified.

For this reason it is of interest to investigate the response pattern of arteries during simultaneous application of potassium and catecholamines. Different and controversial results have been reported concerning the simultaneous action of potassium and adrenaline ${ }^{11,12}$. In this study we have attempted to analyse the reaction of isolated arterial segments during simultaneous or successive administration of the two opposing agents.

Experiments were carried out on isolated segments of bovine facial arteries, which were mounted in a chamber at $37^{\circ} \mathrm{C}$. One end of the segment was connected with a pressure transducer (Schwarzer). After filling with Tyrode solution, the other end of the artery was closed and the pressure was increased to $100 \mathrm{mmHg}$ by means of a Boyle-Mariotte's device. Length tension of the arterial segment was adjusted to $20 \mathrm{~g}$ under the control of a mechano-electrical transducer (Collins). The artery was allowed to adapt to the pressure of $100 \mathrm{mmHg}$ and to the temperature of $37^{\circ} \mathrm{C}$ for $30 \mathrm{~min}$. Then the connection between the Boyle-Mariotte's device and the artery was interrupted and the inside pressure of the segment was recorded isometrically.

The vasoconstriction caused by NA rises sharply from the threshold concentration $\left(5 \times 10^{-7} \mathrm{~g} / \mathrm{ml}\right.$, causing an increase in pressure of about $10-30 \mathrm{mmHg}$ ) to its maximum $\left(5 \times 10^{-6} \mathrm{~g} / \mathrm{ml}\right.$, causing an increase in the pressure of about $150-200 \mathrm{mmHg}$ ). A slight additional increase in the potassium concentration at the height of the NA induced vasoconstriction inhibits the NA effect. The

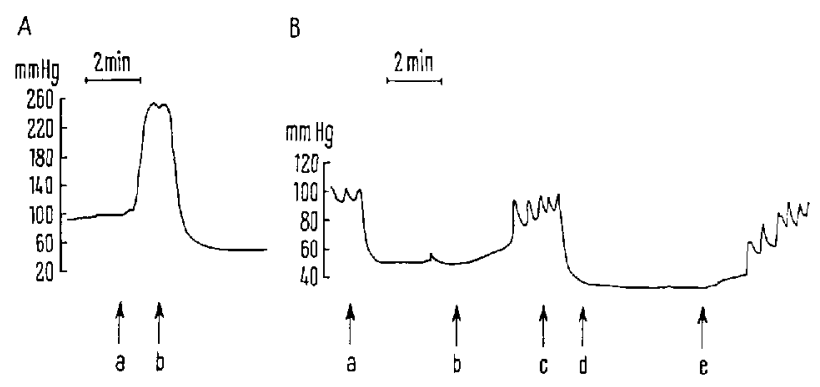

Arrows indicate the application of the different agents in Tyrode solution. A (a) NA $5 \times 10^{-6} \mathrm{~g} / \mathrm{ml}$, (b) $10 \mathrm{mmole} / 1 \mathrm{KCl}$ and $\mathrm{NA}$ $5 \times 10^{-6} \mathrm{~g} / \mathrm{ml}$. B (a) $6.34 \mathrm{mmole} / 1 \mathrm{KCl}$ and $\mathrm{NA} 5 \times 10^{-6} \mathrm{~g} / \mathrm{ml}$, (b) $2.68 \mathrm{mmole} / 1 \mathrm{KCl}$ without $\mathrm{NA}$, (c) $10 \mathrm{mmole} / 1 \mathrm{KCl}$, (d) $10 \mathrm{mmole} / \mathrm{l}$ $\mathrm{KCl}$ and NA $5 \times 10^{-6} \mathrm{~g} / \mathrm{ml}$, (e) $2.68 \mathrm{mmole} / 1 \mathrm{KCl}$ without $\mathrm{NA}$; see text. pressure increased by $5 \times 10^{-6} \mathrm{~g} / \mathrm{ml} \mathrm{NA}$ is reduced by $6.34 \mathrm{mmole} / \mathrm{l} \mathrm{KCl}$ to a value at and by $10 \mathrm{mmole} / \mathrm{l} \mathrm{KCl}$ to a value below starting level (Figure A). In case of simultaneous application, the vasodilating effect of 6.34 mmole/l $\mathrm{KCl}$ dominates persistently over the vasoconstricting effect of NA (Figure B). After a vasodilatation induced by $6.34 \mathrm{mmole} / 1 \mathrm{KCl}$, the additional application of NA $\left(5 \times 10^{-6} \mathrm{~g} / \mathrm{ml}\right)$ sometimes evokes a slight vasoconstrictor response, but this effect could not be observed after a vasodilatation caused by $10 \mathrm{mmole} / \mathrm{l} \mathrm{KCl}$ (Figure B). Similar results are obtained with adrenaline. Adrenaline has no dilating effect in our experiments.

The study shows that the vasodilating effect of potassium inhibits the vasoconstricting effect of catecholamines and that an increased potassium concentration sharply diminishes the responsiveness of isolated peripheral arteries of a muscular type to adrenergic compounds. Since active muscles release a substantial amount of potassium it cannot be denied that the increase in the potassium concentration might counterbalance the increased sympathetic activity. This assumption would correlate to a certain degree with the observation of a local functional sympatholysis during muscular exercise ${ }^{8-10}$. Further experiments on resistance vessels are necessary to prove that the reaction of the investigated peripheral artery is a common principle in muscle flow regulation.

Zusammenfassung. An isolierten Segmenten der Art. facialis (Rind) wurde der Innendruck (Anfangsdruck $100 \mathrm{~mm} \mathrm{Hg}$ ) fortlaufend isometrisch registriert, während die Aussenseite von Tyrode-Lösungen mit verschiedenem Kalium- und Catecholamingehalt umspült wurde. Die durch die Catecholamine $\left(5 \times 10 \mathrm{bis}^{7}-5 \times 10^{-6} \mathrm{~g} / \mathrm{ml}\right)$ induzierte Vasokonstriktion kann durch geringe Erhöhung der Kaliumkonzentration (von 2,8 auf 6,34 bis ca. $10 \mathrm{mmol}$ ) unterdrückt worden. Bei gleichzeitiger Applikation beider Substanzen setzt sich die dilatatorische Wirkung der $\mathrm{K}^{+}$Ionen durch.

P. Konold, G. Gebert and K. Brecht

Physiologisches Institut der Universität, 74 Tïbingen (Germany), 8 March 7968 .

1 W. O. Fenn, R. H. Koenemani, B. V. Fayata and E. T. SheriDAN, Am. J. Physiol. 131, 494 (1940).

E. H. Wood, D. A. Collins and G. K. Moe, Am. J. Physiol. 128, $635(1939-1940)$

I. KJELlMER, Acta physiol. scand. 63, 460 (1965).

4. KJELLMER, Med. exp. 5, 56 (1961).

5 P. Konold, G. Gebert and K. Brecit, Experientia 24, 247 (1968).

6 O. L. Wade, B. Combes, A. W. Childs, H. O. Wheelers, A. Cournand and S. E. Bradley, Clin. Sci. 15, 457 (1956).

7 D. A. Blair, W. E. Glover and I. C. Rombie, Circulation Res. g, 264 (1961).

I. KJEllige, Acta physiol. scand. 63, 450 (1965).

9 H. Rein, Klin. Wschr. 9, 1485 (1930).

10 J. P. Remensnyder, J. H. Mitchell and S. J. Sarnoff, Circulation Res. 9, 370 (1962).

11 D. F. Bohr, D. C. Brodie and D. H. Cireu, Circulation Res. 17, 746 (1958)

12 D. F. Bohr and P. L. Goulet, Am. J. Cardiol. 8, 549 (1961). 